\title{
Tourism discourse: Languages and banal globalization
}

\author{
CRISPIN THURLOW and ADAM JAWORSKI
}

\section{Abstract}

Described as the "one of the greatest population movements of all time," tourism is firmly established as one of the world's largest international trades. And it is not just people who are on tour; language too is on the move. In this paper we examine some of the ways that our research has shown language commonly being taken up in tourism's search for exoticity and authenticity. Specifically, we present a series of different touristic genres (broadcast media, guidebook glossaries, guided tours) where local languages are stylized, recontextualized and commodified in the service of tourist identities and of tourism's cosmopolitan mythology. It is in this way that the globalizing habitus (Jaworski and Thurlow 2010) of tourism privileges or elevates those who choose to travel, containing linguistic/cultural difference under a guise of celebration and respect. These playful, seemingly innocuous "textualizations" of language/s are also exemplary enactments of banal globalization (Thurlow and Jaworski 2010), the everyday, micro-level ways in which the social meanings and material effects of globalization are realized.

Keywords: language, local languages, tourism, commodification, cosmopolitanism, difference, banal globalization, globalizing habitus

Touristic culture is more than the physical travel, it is the preparation of people to see other places as objects of tourism ... the touristic gaze and imaginary shape and mediate our knowledge of and desires about the rest of the planet. (Franklin and Crang 2001: 10)

Symbolic capital, a transformed and thereby disguised form of physical "economic" capital, produces its proper effect inasmuch, and only inasmuch, as it conceals the fact that it originates in "material" forms of capital which are also, in the last analysis, the source of its effects. (Bourdieu 1977: 183) 


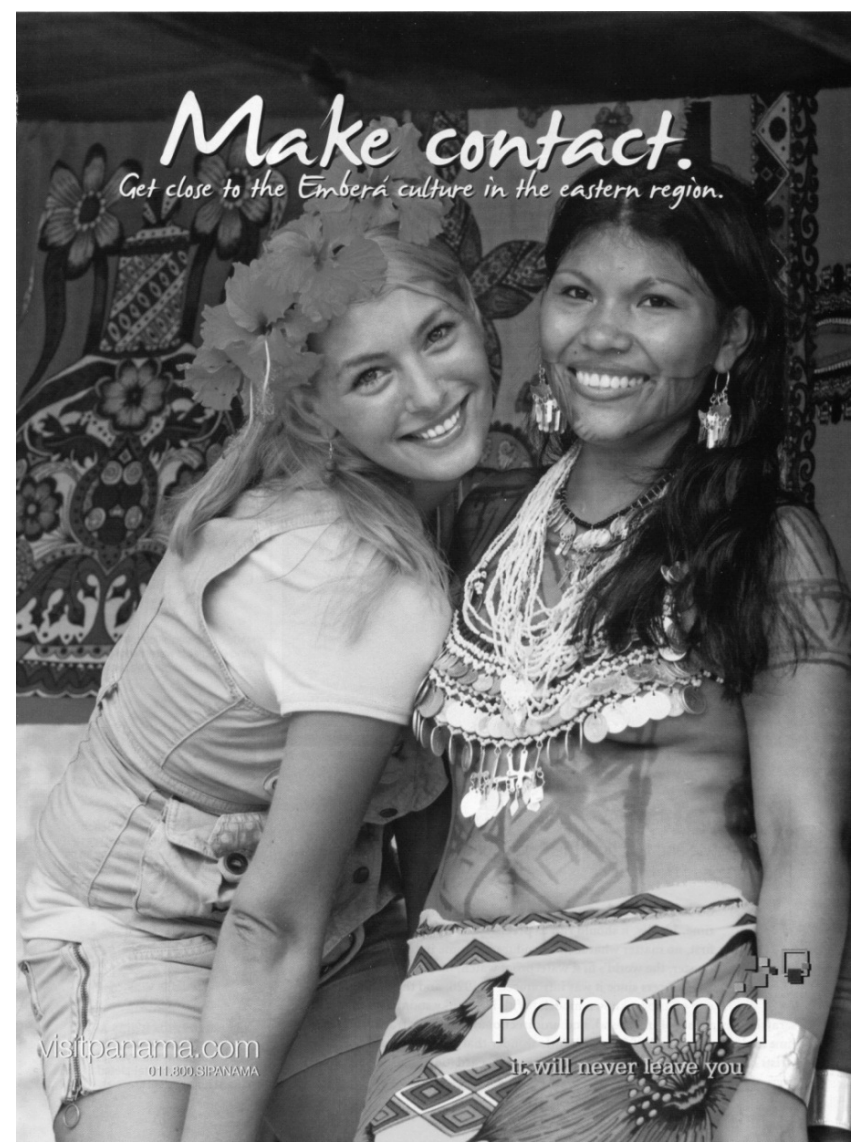

Figure 1. The promise of contact

\section{Why tourism matters (for language scholars)}

Academics working in the interdisciplinary field of critical tourism studies often have to justify their scholarly interest to those unable to see beyond their own personal experience of tourism as a frivolous, recreational activity. And yet, as a truly global industry - perhaps even the world's largest, single international trade - there are few people whose lives remain unaffected by tourism, be it people privileged enough to tour or people who are "toured". For anthropologist Ed Bruner (2005: 10), tourism is simply "one of the greatest population movements of all time". It is precisely because of its scale and influence that anthropologists, sociologists, geographers and others have looked to examine the 
social and cultural practices by which tourism is organized and experienced (for an overview, see Thurlow and Jaworski 2010). As a whole, this growing body of research clearly demonstrates tourism's powerful role in reshaping cultural practices, establishing ideologies of difference, and perpetuating unequal relations of power (Favero 2007). Tourism seldom merely represents cultural difference or reflects existing socioeconomic relations within and between countries; instead, it is instrumental in producing the very culture that tourists set out to know, and in (re)organizing relations between groups, communities and entire nations (Lash and Urry 1994; Bauman 1998; Kirshenblatt-Gimblett 1998). As Adrian Franklin and Mike Crang note (quote above), tourism serves as a very influential, privileged lens through which many people make sense of not only a particular destination or "culture" but of the world at large.

In seeking to contribute a uniquely sociolinguistic or discourse analytic perspective to the field of tourism studies, our own work focuses on the role of language and communication in tourism. More importantly, however, we are keen to learn what tourism tells us about language and languages nowadays. We therefore share with other colleagues a broader interest in understanding the life of language/s under globalization or, more correctly, postindustrial capitalism (see, for example, Heller 2003; Blommaert 2005; papers in Coupland 2010). Just as tourism has proved to be an obvious research domain/topic for anthropologists and sociologists, it is a key site for the study of human communicative processes - most obviously with regards intercultural contact and exchange, but also in terms of the circulation of linguistic "material" (e.g. genres, discourses and styles). For all its economic weight and political consequence, tourism is an intensely social and communicative business. In many respects it is the ideal industry for global capitalism because it is highly flexible, constantly reflexive and deeply semiotic

As a service industry, tourism is fundamentally - and, at times, solely semiotic in nature because, like advertising and marketing, a key part of what is actually produced and consumed is the semiotic context of the service. Not only does tourism involve face-to-face (or more mediated) forms of visitor-host interaction, like in many other types of service interactions, but the ultimate goods purchased by tourists during their travels are images, lifestyles, memories, tastes, "encounters", and so on. Much of the significance - the cultural capital - of tourism lies also in the "tourist haze" created as tourists return home with their own travel stories about well-trodden destinations, the souvenirs they bring for "the folks back home", and indeed the photos of themselves in exotic locations. More than this, however, the tourist imagination and tourist practices are always heavily (in)formed by - and prefigured in - the heavily mediatized representations of television holiday programmes, travel brochures, newspaper 
travelogues, postcards, guidebooks and so on (see Thurlow and Jaworski 2010). In this way, as Mike Crang (1999: 361) explains, "a structure of expectation is created, where the pictures circulating around sights are more important than the sites themselves ... The signs that mark out what is to be looked at become as, or more, important than the sites themselves." With particular reference to photography, John Urry (2002) calls this search for the already seen the hermeneutic cycle:

What is sought for in a holiday is a set of photography images, which have already been seen in tour company brochures or on TV programmes. While the tourist is away, this then moves on to a tracking down and capturing of these images for oneself. And it ends up with travellers demonstrating that they really have been there by showing their version of the images that they had seen before they set off. (p. 129)

What we mean to show in this paper is that language, languages and, in particular, local languages often feature no less heavily than photos/images when it comes to tourists' search for authenticity and difference. Along with material goods such as photographs and souvenirs, snippets of local languages too are (re-)packaged and promoted as useful props (or trinkets) in the enactment of tourism's performances of exoticity. The tourist linguascape (Jaworski et al. 2003) thus serves as an extension of the tourist gaze (Urry 2002, after Foucault 1976), the socially organized, systematized and disciplining ways in which tourism is structured and learned. In the case of language, tourists are also drawn into a regime of truth about the nature of language and "linguaculture" (Agar 1994), as well as the relative value of local languages in the global linguistic marketplace.

\section{Tourism as a language market}

Until not so long ago, tourism research tended to focus almost exclusively on the role of visuality, spurred in large part by John Urry's commonly misunderstood notion of the tourist gaze just mentioned. To be sure, the visual representation and production of sights/sites continues to be a dominant mode for visitors and hosts. It is, however, by no means the only sense through which travel is experienced (see Franklin and Crang 2001). To some extent, any lack of scholarly attention to language is explained by the nature of the tourist experience itself; in Michael Cronin's (2000:82) words, "sightseeing is the world with the sound turned off". As David Dunn $(2005,2006)$ further explains, tourists usually end up gazing simply because they cannot understand the languages spoken by the 
objects of their gaze. And yet, our own research suggests that language (along with other communicative modes) is everywhere in tourism; in fact, language and languages sit at the very heart of the tourist experience, its representation and its realization, its enculturation and its enactment.

The expansion of tourism as a dominant cultural industry is one of the major areas of economic activity under globalization which has highlighted the significance of language commodification in the study of shifting identities, interpersonal relations and group structures. Of course, the political economy of language has long been recognized (e.g. Bourdieu 1991; Irvine 1989), and so have the general processes of commodification and appropriation of language in the new economic order of flexible accumulation and of time-space compression. In her work on bilingual areas of francophone Canada, for example, Monica Heller (e.g. 2003) demonstrates how the collapse of traditional industries (cod-fishing, mining, logging, etc.) in the second half of the twentieth century, and their substitution with new information and service-based industries (most notably, call centres and tourism), have led to the commodification of both language (understood as a measurable skill) and identity (especially in relation to other forms of cultural practice such as dance and music in tourism). In these domains of economic practice based on contact between different linguistic markets through advances in communication technology (call centres) or mobility (tourism), linguistic and other symbolic resources become highly marketable commodities.

Due to the new conditions for its commodification, language, together with other forms of cultural practice, is arguably more easily detached from identity and used as a strategic styling resource (cf. Bell 2009; Cameron 2000; Coupland 2007). One place where this happens often is in tourism discourse where local languages may be marketed and traded as "metonyms of place" (Urry 2007) and/or markers of cultural authenticity to be consumed by tourists. It is this that we mean to show now by turning to some data which illustrates just some of the ways that language/s is/are commonly - and, we suggest, problematically - taken up in tourism discourse. To this end, we want to look at three examples: travel shows, guidebook glossaries and what we like to call the "greeting game". We end with a more critical/social theoretical reflection on the politics of representation and the implications of tourism's use of local languages. The issue for us is one of language ideology as it dovetails with the ideologies (or mythologies) of both tourism and globalization; in each case, and as Bourdieu (quote above) reminds us, the symbolic market - however insubstantial and playful it appears is grounded in the material inequalities of the global political economy. 


\section{Case study \#1: The language play of travel shows}

The broadcast media offer some of the quintessential ways in which tourism is pre-figured as "the preparation of people to see other places as objects" (quote by Franklin \& Crang above). In other words, people learn what the value of tourism is, what it means to be a tourist and the "rules of engagement" with local places, local people and, indeed, local languages. Take a look at the following extract from the start of one episode of the popular (in the USA, at least) radio show Travel with Rick Steves. (We will show shortly that this singular moment of tourism discourse is by no means limited to Rick Steves, to radio or to the USA.) This episode was first aired in May 2008 and was repeated in January 2010; it is Steves' Rome City Guide. After a short preamble (lines 1 to 5, edited from the original), he takes a moment to introduce two local guides/friends, starting in line $6 .{ }^{1}$

\section{Extract 1: From Travel with Rick Steves (10 May 2008)}

1 RS: as you peel through its fascinating and jumbled layers you'll find

11 RS: benvenuti

12 SP: (laughs)

13 RS: Francesca come va?

14 FC: (laughs) molto bene e tu?

15 RS: ciao bella (laughs)

16 FC: (laughs) ciao

17 SP: (laughs)

18 FC: (laughs)

19 RS: I gotta say ciao bella

20 FC: si

21 SP: yeah you said it well

22 FC: yeah that was perfect

23 RS: ciao bella because I wouldn't want to say ciao bello

24 FC: (laughs) no you wouldn't

25 RS: I've learned (.) no 
26 FC: definitely not (laughs)

27 RS: OK thank you (.) well it's great to have you both here

Steves' performance of Italian (and Italianicity more generally, cf. Barthes 1977 [1964]) confirms his relatively limited grasp of the language; for example, his incorrect gendered inflection of "benvenuti" (line 9), his inability to recognize the correction offered (lines 10 and 11), the arguably pragmatic inappropriateness of "ciao bella", and, by the same token, his slightly awkward (if not also heteronormative) game with "bello". This is not to say that he has no Italian. Nor is it to deny credit where credit is due: at least, some might argue, he's having a go. This is hardly, however, a serious or committed attempt to take up or to move into Italian. Indeed, the framing of this local language as a largely playful resource for use by Steves is keyed as "endlessly entertaining" (line 3) in his preamble and by the laughter throughout (lines 12, 14, 15, 16, 17, 18, 24 and 26). It's a low-stakes game, all part of a pleasurable encounter with otherness. Steves rests comfortably in the knowledge that after his dabble with Italian he may return safely to English - after all, both his Italian guests are fluent English speakers. Note also the promise of contact (see "opportunity to connect", line 5) which sits at the heart of so much tourism discourse. In a world (or interactional frame) marked as play, grammatical accuracy is clearly less important - if at all - and the consequences of pragmatic failure - the need for serious conversational "repair - mitigated by largely one-sided relationships of power. At least this is how these encounters are presented to listeners or, as we will now show, viewers.

Across a lot of our research, we have found much the same playful framing of local languages in different domains of tourism discourse (see Jaworski et al. 2003; Jaworski and Thurlow 2009; Thurlow and Jaworski 2010). For now, however, we present the following short extracts from once hugely popular British television holidays shows; these extracts are just four instances where a presenter is seen to use a local language. To be clear, the depiction of local languages does not happen often in shows like these which are for all intents and purposes "infotainment" targeted at predominantly English-speaking audiences. We start with Extract 2 - as it happens, another performance of Italianicity - to exemplify the deployment of a local language as an ideal marker of authenticity and/or as an exotic backdrop.

\section{Extract 2: Vera, the chief pasta maker and TV presenter Mary Nightingale}

$1 \mathrm{MN}$ : (voiceover) I found all the hotels very comfortable and what's nice is

2 they're all so individual and they feel so (.) Italian (1.0) this farmhouse

3 has been in the family for generations (.) Vera is the boss (.) and the 


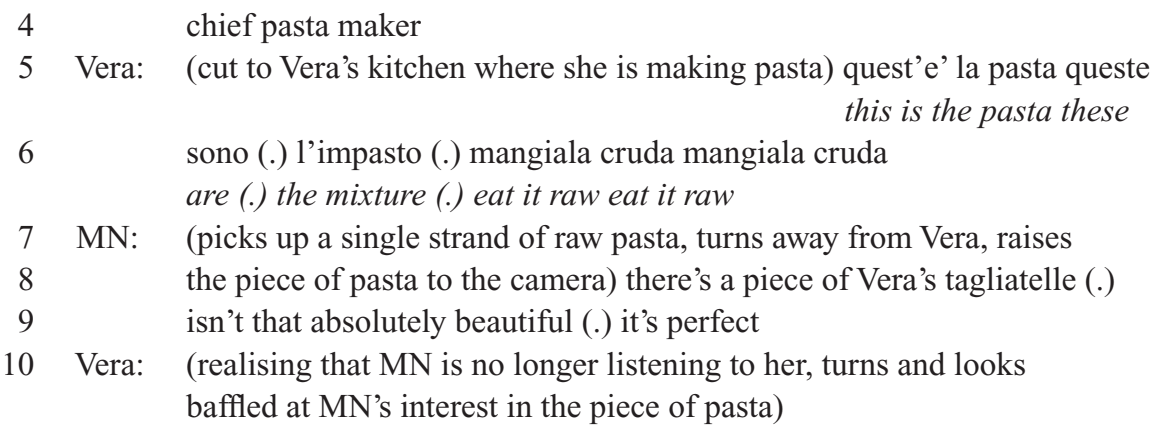

In this extract, Italian is spoken only by the local expert (Vera) who is cast for her stereotypical expertise as the "chief pasta maker" whereby pasta once again metonymically condenses all things Italian (it all feels "so Italian", line 2). In turning to the camera midway through Vera's instructions, the presenter confirms the primary interactional alignment (with the audience "back home") and proves that Vera's talk is really intended as little more than another scene-setting resource. It is not what Vera is saying that is important but rather that she is simply saying something in Italian while making pasta. The person, the food and the language all serve as metonymic markers of place and of difference. The use of local languages as exotic backdrop or soundscape is one of the most common ways in which the tourist linguascape is produced (again, see Jaworski et al. 2003; Jaworski and Thurlow 2009; Thurlow and Jaworski 2010). In Extract 3 , we find the relegation of a local language extended through its use as a ludic resource, as an object of play. In this case, the tourist-presenter (CD) is interacting with "larger than life" store-keeper Massimo.

\section{Extract 3: Ciche ciche cento-Massimo and TV presenter Craig Doyle}

1 CD: (voiceover) the Italians are passionate about food and no one more so

2 than Massimo one of Siena's larger than life grocers

3 M: grande grande $=$ large large

4 CD: =grande large

5 M: questo è pesto pesto genovese (.) guarda (picks up a packet of pasta) this is pesto pesto from Genoa (.) look

$6 \mathrm{CD}$ :

[

$7 \quad$ so I need these as well yeah (picks up a tray of blackberries)

9 M: avanti 


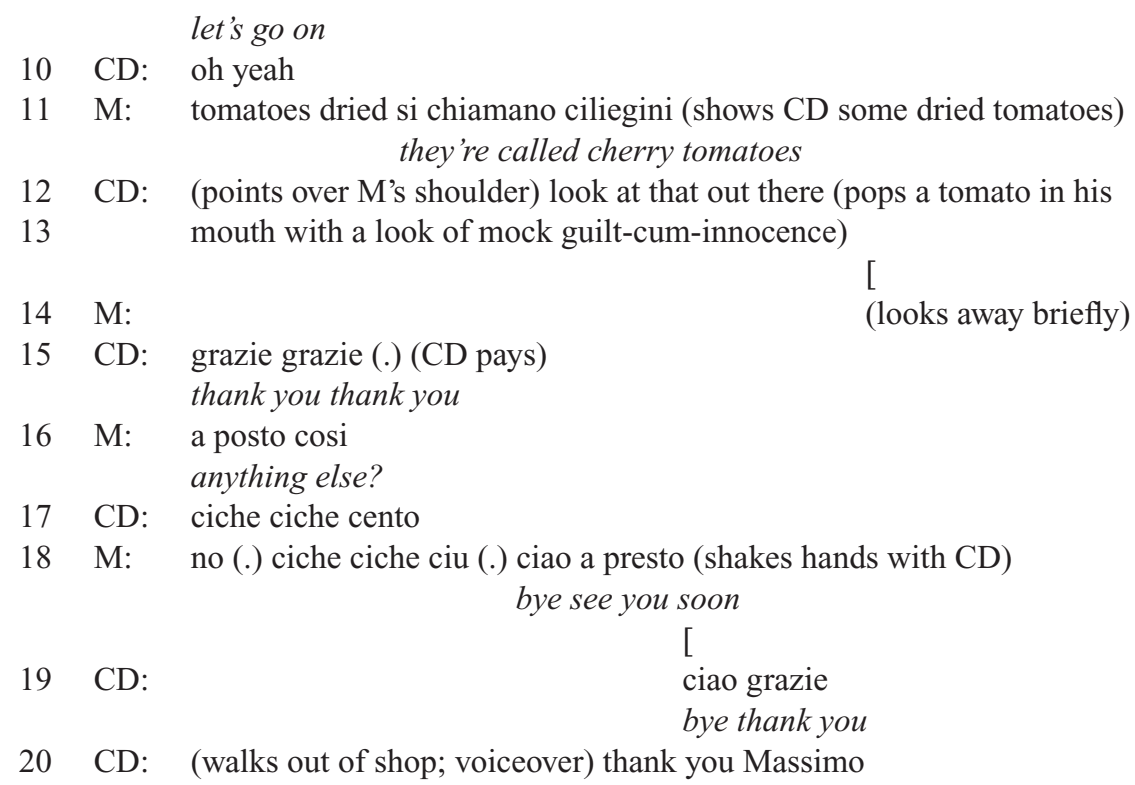

It is worth noting that this last extract (like Extract 4 below) is also structured by a musical score - in this case, a lively swing-jazz tune, ideal for the kind of comedic sketch being staged. Rather like Rick Steves above, the presenter here clearly has only a basic grasp of Italian; while Massimo presses on with explaining his produce, the presenter throws about one or two familiar snatches of phrasebook Italian ("grande" line 4, "si" line 6, "grazie" lines 15 and 19, and "ciao" line 19) and finishes with the largely nonsensical "ciche ciche cento" (line 19) - a phrase which possibly, for a British audience at least, echoes the Cinquecento from Italian car manufacturer Fiat (which was also being heavily advertised at the time this show was first broadcast). For the presenter, it is all just a game for the benefit of the folks back home; both Massimo and Italian are just props in his skit. To match his somewhat condescending interaction with the local person, the presenter also "condescends" into the local language in precisely the way that Pierre Bourdieu (1991: 69) explains it:

One can see in passing that strategies for the subversion of objective hierarchies in the sphere of language, as in the sphere of culture, are also likely to be strategies of condescension, reserved for those who are sufficiently confident of their position in the objective hierarchies to be able to deny them without appearing to be ignorant or incapable of satisfying their demands.

None of this is to deny the fun of trying out snippets of the local language, although this enjoyment should not conceal the privilege of not really having to 
depend on the language. The pleasurable value of local languages for tourists (as presenters or otherwise) is commented upon explicitly in Extract 4, where the presenter (LR) excitedly tries out her one line of Spanish in a service encounter with a barman. Pragmatic matters such as the arguably inappropriate use of the familiar t-form ("puedes") are again less important than the pleasure of learning and "having a go".

\section{Extract 4: Been learning that all day! (with TV presenter Lisa Riley)}

1 LR: (voiceover) it's well worth taking a wander up the side streets off the 2 square (camera on LR and friend) where you can find traditional tapas 3 bars just like this one (points to bar) ((shall we take a look)) (LR walks $4 \quad$ to bar; to barman) hola me puedes dar la carta por favor?

5 Barman: (hands over menu) ((unclear))

6 LR: gracias (to camera, cheerfully) been learning that all day (giggles) thank you

Throughout these types of mediatized instances of local language, what is shown is only the most superficial form of engagement with local people (almost always in service ecounters - see below) as an arch performance of contact. In one of our favourite moments - and the last one we will present here - Extract 5 points again to the playful but very limited use of the local language (the one-word greeting "bula" in line 3) but is also a clear reminder that the use of local languages is invariably a theatrical prop for staging hospitality and reassuringly friendly local people. In this particular case, all we want to show is how the highly scripted/staged nature of these types of televised encounters with hosts is accidently revealed: note the easily missed use of the TV presenter's name by the vendor in Line 5.

\section{Extract 5: Bula, bula, John! (with TV presenter John Savident)}

$\begin{array}{lll} & & \text { (JS apparently wandering through a market place) } \\ 1 & \text { JS: } & \text { away from the hotel the town of Nandi [sic.] is just ten minutes away (.) } \\ 2 & & \text { Fiji is such a friendly place and you're always greeted with a big smile } \\ 3 & & \begin{array}{l}\text { (cut to a woman smiling) and a call of ((BULA)) the local greeting } \\ \text { (to a street vendor) bula }\end{array} \\ 5 & & \text { Vendor: } \\ 6 & & \begin{array}{l}\text { bula bula John (JS continues walking past her stall, laughs to her) how } \\ \text { are you bula bula la la la }\end{array}\end{array}$

In her study of the use of "mock Spanish" by Anglo-Americans in the United States, for example, Jane Hill (2001[1998]) demonstrates how apparently jocular incorporations and ungrammatical approximations of other languages are 
employed by non-native speakers as an important identity resource. Hill argues that playful, flippant snatches of, in her case, Spanish-language materials, serve to elevate the identities (or Whiteness) of Anglo-Americans. To our mind, much the same argument may be made for the use of "phrasebook" (see next section) expressions by presenter-tourists and the general linguascaping of tourist destinations; in this case, however, it is the elevation and constitution of Americanness by Rick Steves and Britishness by the TV presenters which is at stake.

In fact, we argue that the main aim in both cases (radio and TV) is to create for the listeners/viewers a pleasing sense of belonging to an imagined community of tourists and cosmopolitan global citizens. This is achieved largely through the presenters' specific exploitation of the sociolinguistic resource known as crossing (see Rampton 1995) which is the use of a language (or variety) of a group of which the speaker cannot legitimately claim membership. It is through their playful, transient crossings into local languages that these presenters position themselves as "cosmopolitans" - not in the sense of their being culturally engaged with or embracing local people (cf. Hannerz 1996), but rather with respect to their appeals to the elite cachet of global citizenship. These are people freely traversing national boundaries but staying firmly rooted in their mutual identification as (American and British) nationals. Ultimately, it is in this way also that, as powerful ideological mediators, the shows and their style-setting presenters promote a regime of touristic and intercultural truth: this is what it means to be a tourist, this is where the value of local languages lies.

\section{Case study \#2: "Language learning" in guidebook glossaries}

We turn now from our broadcast data to a different set of data: the glossaries of travel guidebooks as a quintessential genre in tourism and of what we like to call a "discourse on the move" (Thurlow and Jaworski 2010). These highly condensed "crash courses" tucked away at the end of most guidebooks are also in the business of stylizing tourists and of commodifying local languages; they often go a step further, however, by purporting to offer workable scripts for intercultural contact between tourists and hosts. In this case, as with the advertisement in Figure 2, the exaggerated promise of contact produces a number of questionable ideas about the nature of language, of language learning and of human interaction in general.

The representation of local languages in guidebooks - indeed, the decision itself to include a section on the local language/s - is structured by a desire to produce authenticating markers of exoticity and cultural difference. In this sense, the glossaries are no different from the kinds of playful linguascaping 


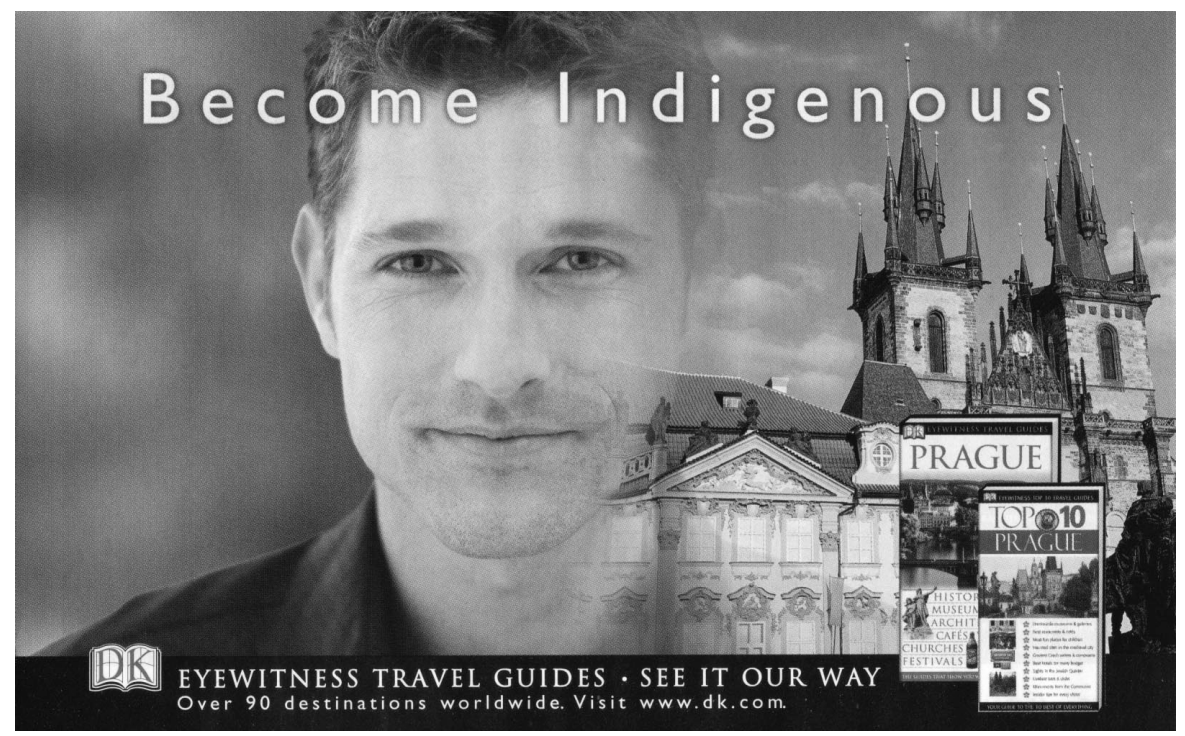

Figure 2. The promise of contact $\# 2$

we showed above. Not surprisingly, therefore, many guidebooks begin with a metalinguistic commentary on the perceived oddity of the local language; in doing so, they rehearse a number of common language myths about, for example, how hard or different the language is, or how beautiful or ugly it is (cf. Bauer and Trudgil 1998). From an expert point of view, of course, these are always only ever matters of subjective or relative taste and of ideology. This explains why Polish should be "fearsome" (Extract 6a) and Australian Strine is "laconic", "poetic" and "prolific" (Extract 6b). It is a matter of ideology (not linguistics) that the inclusion of a Strine glossary thereby also renders it equivalent to Polish or any other major (national) language typically covered in guidebooks.

\section{Extracts 6 a to $6 f$}

a. ... Polish is pretty fearsome for people outside the Slavonic circle ...

b. The lingo has a laconic, poetic originality and a prolific profanity.

c. Chinese languages are rich in homonyms and much of their superstitious beliefs, poetry and humour is based on this wealth. The Cantonese word for "silk" sounds the same as the words for "lion", "private", "poem", "corpse" and "teacher".

d. Fortunately, staff at most tourist offices and hotels are fluent English speakers ...

e. ... Mexicans are delighted with foreigners who try to speak the language ...

f. Mistakes made by visitors are kindly tolerated, and even your most bumbling attempts [at Finnish] will be warmly appreciated. 
In Extract 6a, popular stereotypes about Chinese/Cantonese are the focus of guidebook commentary. While it is true that Cantonese is rich in homonyms, that language play and verbal taboo are frequent, it is also true that beyond the 'simple' citation forms, all the words listed in the second sentence of the extract are easily disambiguated in spoken Cantonese due to their bi-morphemic (two character) structure, presence of classifiers, and other morpho-syntactic features. What this description also overlooks - or downplays - is that the very same principles are true of most languages; for example, an easy equivalent might be English homonyms like "pore, poor, pour" or "rain, reign, rein" or "raise, rays, raze", which in Spanish, say, would be rendered differentially as "poro, pobre, verter", "lluvia, reinado, reinda", and "aumento, rayos, arrasar", respectively. (And this is not to mention the relative challenge of the idiosyncrasies of English spelling). Of course, the real value in pointing to grammatical and phonetic characteristics such as these does not lie in their linguistic validity or significance, but rather in their perceived oddity and, therefore, implied exoticity. Once again, in the context of tourism, language is given value (and attention) because of its symbolic rather than representational or interpersonal function.

This is why local languages are seldom presented as any real obstacle or necessity. For the most part, guidebooks assume English as the default language of exchange, often reassuring readers that locals can manage English (e.g. Extract $6 \mathrm{~d}$ ) or even that locals are "delighted" or "warmly" appreciative of any attempts by the tourist to speak the local language (Extracts 6e and 6f). Ultimately, of course, interactions between hosts and tourists are structured by the realities of economic-political exchange whereby the "burden of communication" (Lippi-Green 1997) always falls squarely with the host. This relationship of inequality is articulated throughout the design and content of guidebook glossaries.

As part of their wider Small Talk series of guides, the Lonely Planet promises to help tourists "Chat, eat, shop and celebrate your way through the wonders of Northern Europe". Meanwhile, DK Eyewitness' 15-Minute Spanish claims to teach tourists how to "Order a meal. Book a room. Buy a ticket. Ask directions. Make conversation". The highly optimistic promise of a more conversational exchange (or "chat") is intriguing and begs a closer look at the kind of conversational material on offer. What is striking is not only the limited prescription of communicative topics but also assumptions made about the nature of the relationship between visitors and local people. The vocabularies on offer are clearly restricted to the functional requirements of service transactions (that is, "how much is ...?", "where can I find ...?" and so on); alternatively, they encourage a level of relational engagement that seldom ventures beyond the superficial 
courtesies of greeting rituals (for example, "hello", "good morning", "my name is ...", "I am from ..."). Almost never is there a vocabulary made available which might otherwise help facilitate a more substantial, extended exchange or conversation - even at the most basic level, say, of "I like my job because ...", "This is the first time I've ...", "I believe that ..." and so on. There is certainly little in these glossaries that might move visitors towards the kind of intercultural, cross-lingual encounter with the Other which sits at the heart of tourism mythology and which the guidebooks themselves consistently imply. Instead, glossaries leave tourists stranded in a permanent state of greeting, introduction and purchase - perhaps appropriate to the liminal, fleeting nature of most host-tourist encounters.

On close inspection, the glossaries suggest to us that apart from the most phatic exchanges (greetings, leave-takings, expressions of thanks, and so on) and the tourist-centred needs of getting to a specific location, getting a good night's sleep (possibly in a room with a view), finding a meal and a toilet, getting a good bargain in a shop or at a market, the most likely situation in which the tourist will want to speak to a host is in an emergency. To some extent, this goes some way towards contradicting the mythology of travel as being always safe and pleasurable. The preponderance of words and phrases related to accidents, illness and all sorts of other mishaps could provide a useful script for any travel insurance company advert. The following is a relatively unordered list of the English language phrases to be used in case of an emergency.

Help!
Watch out!
Thief!
Fire!
Stop!
Call a doctor!
Call the police!
Call an ambulance!
Call the fire department!
Where is the nearest hospital?
I want to contact my embassy
Could I use the telephone?
Could you help me, please?
I'm ill
I'm sick
I'm injured
I do not feel well
I feel ill

Help!

Watch out!

Fire!

Stop!

Call a doctor!

Call the police.

Call an ambulance!

Call the fire department!

Where is the nearest hospital?

I want to contact my embassy

Could I use the telephone?

Could you help me, please?

I'm ill

I'm injured

I feel ill

\author{
I have a headache \\ I have a stomach ache \\ I need to rest \\ I have a fever \\ I'm allergic to penicillin \\ I'm allergic to antibiotics \\ The child is/the children are sick \\ We need a doctor \\ I need a prescription for \\ cold \\ cough \\ cut \\ flu \\ hayfever \\ headache pills \\ hospital \\ nausea \\ sore throat
}




$\begin{array}{ll}\text { dentist } & \text { police } \\ \text { doctor } & \text { policeman } \\ \text { thermometer } & \text { foreign affairs police } \\ \text { drug store } & \text { pickpocket } \\ \text { medicine } & \text { rapist } \\ \text { pills } & \text { I've been robbed } \\ \text { accident } & \text { I've/we've been mugged } \\ \text { ambulance } & \text { They stole my ... } \\ \text { emergency } & \text { I'm lost }\end{array}$

For the most part, the language instruction in glossaries centres on the transactional demands of service encounters rather than the interactional demands of a conversational relationship. And yet, a close examination of the language information provided in tourist guidebooks shows that there is rarely sufficient information to conduct anything but the most rudimentary of conversations. Although tourists might be encouraged to believe they are becoming global communicators and acquiring a global linguistic repertoire of tourism by using the language sections, the focus on the practicalities of travel and transactional language contrasts with the common myth of travel broadening the mind. Take a look at our hypothetical compilation of a typical range of "conversational" phrases offered in the guidebooks we sampled:

Welcome! Hello Glad to meet you. How are you? Very well, thanks. What's your name? My name is ... Where are you from? I'm from ... I'm a tourist/student I'm from Europe. How old are you? I'm 25 Are you married? How do you say ... No (not so) Yes I want ... No. I don't want it. Do you like ... ? I like it very much I don't like ... May I? It doesn't matter. Can you please help me take a photo? Is it ok to take a photo? Goodbye.

Any conversation based on this vocabulary would unavoidably be something of a one-way street; this is clearly not a vocabulary of exchange but merely of encounter whereby the local person (imagined in bold) remains, for the most part, "unspoken" and unknown. Certainly, the DK Eyewitness promise made in Figure 2 of becoming somehow "indigenous" seems highly improbable if this is all the small talk one can muster. Guidebook glossaries are prime examples of what we have elsewhere characterised as "codified, fixed regimes of translated truth which ... promote the literal and denotative, the formulaic and reductive, at the expense of the subtle, the complex, the messy, the 'lived"' (Thurlow 2004: 83). In fact, the very raison d'etre of guidebooks is, somewhat ironically in the case of glossaries, to minimize or at least mitigate contact with local people. It is in much the same way that Daniel Boorstin (1964: 91) commented some time ago on the effect travel agencies had in "insulating the tourist from the 
travel world" (cf. Bhattacharyya 1997; Jack and Phipps 2003). And herein lies the central contradiction of guidebooks.

It is clear from the inclusion of language glossaries in the guidebooks that publishers feel that they need to cater for the eventuality of host-tourist interaction. On the one hand, therefore, tourists carry glossaries to aid with host-tourist communication, but on the other, the need for tourists to interact with hosts is reduced if they use a guidebook. Glossaries function primarily to fulfil the ludic and identificational needs of tourists, which we talked about in more detail above, and in this regard they are more than adequate. To be fair, tourists who want to go further can always turn to a phrase book or a language course. As a whole, however, guidebooks usually play with the backstage frisson, the mythologized desire of tourists to seek the otherwise illusive authenticity of a "real" connection or a "genuine" encounter with the "true" Other. In this way, language glossaries promote themselves as resources for cracking the code of the local and for crossing into alterity. There is inevitably a satisfying and enjoyable sense of mastery in both these processes; it is an almost narcissistic - which is not to say necessarily inconsiderate or maleficent - delight.

As generic practices in themselves, the word/phrase listings included towards the end of virtually all guidebooks are fairly unique, with nothing of the attempted scope of dictionaries or language coursebooks, little of the relative detail in phrasebooks, they typically share the superficial, incidental quality of glossaries. In the rote learning tradition of the audio-lingual language learning methods and with the pretence of the "real-life" notional-functional method (see Pennycook 1989, for a critical review), this is language instruction that stops well short of communicative competence and that seldom goes much further than a foreign-language translation of "Do you speak English?" (cf. Phipps 2007). Language is, in the process, abstracted and rendered simultaneously representative of and autonomous from its cultural context. As such, it is not only the local language that is reduced, packaged and glossed but also, of course, the local culture more generally. These are, after all, the quintessential texts of the quintessential "culture industry of otherness" (Favero 2007).

Ultimately, the tourist linguascape presented in guidebook glossaries is one of language/s almost totally disembedded from the cultural context of any plausible, extended host-tourist relationship - even though the expectation (or promise) is that these linguacultural snippets might eventually be deployed in the service of intercultural exchange. Even then, however, these presumed relationships (or interactions) are clearly predicated on (and work to reinscribe) an asymmetrical model of communication and thus the the host-tourist relations of power by which tourism is typically organized. 


\section{Case study \#3: The greeting game in guided tours}

We turn now to our final case example of a touristic genre where local languages are stylized, recontextualized and commodified. Perhaps the quintessential marker of the hospitality underpinning the tourist-host contract, greetings are everywhere in tourism, whether it is the cover of South African Airways' inflight magazine Sawubona, postcard greetings from the eponymous "Aloha State" or the bore da from Wales, a personalized online greeting from California's Governor and First Lady, or the performance of the Maori hongi in New Zealand's official branding of itself (see Figures 3 through 7).

In each case, greetings such as these are recontextualized and commodified in ways that violate their "normal" felicity conditions (Duranti 1997). The hongi, for example, has become one of the key resources for "packaging" Maori heritage across New Zealand's tourist landscape. In Tamaki Maori Village in Rotorua, tourists can have a picture taken in a makeshift photographic studio of doing a hongi with an actor and images of Maori people performing a hongi can also be bought on postcards and posters (see Jaworski 2009; Jaworski and Thurlow 2010). In reality, it is virtually impossible for a tourist to perform a hongi with a Maori person other than in the context of a paid performance. As with the kinds of scripted exchanges in guidebook glossaries, any attempt by a tourist to initiate a hongi would be pragmatically fraught. Once again, therefore, a linguacultural snippet is taken up as a largely metacultural token or curiosity for authenticating a touristic spectacle of difference.

Our final example is in fact an instance of a commodified greeting exchange (involving a hongi) between a Maori guide/coach driver and an American tourist en route for a night's entertainment at Tamaki Maori Village at Rotorua, New Zealand. The tourists are collected by several coaches from hotels in the area. Once all the tourists are on board, their designated bus (waka, "boat", "vessel"), the guide/ driver welcomes everyone and announces that the tourists will not only experience Maori song, dance, food, etc., but will also "become" Maori for the night. Each busload of tourists is branded as a "tribe" (iwi) with a "chief" (rangatira) ("elected" from among the tourists; the chief seems to usually end up being white, male, American), and the driver offers to "teach" the tourists some Maori language - typically just one phrase/ greeting formula Kia Ora, "Hello/ Good Luck/ Good Health/ Thank You" (cf. Auger 2002), which may be emically more significant than the category "greeting" usually implies, though we surmise that most international tourists remain oblivious to these pragmatic subtleties. Kia Ora is, then, to be repeated in unison by the tourists following a prompt from the guides and other performers. The "chiefs" become privileged participants in representing their "tribes" in the Vil- 

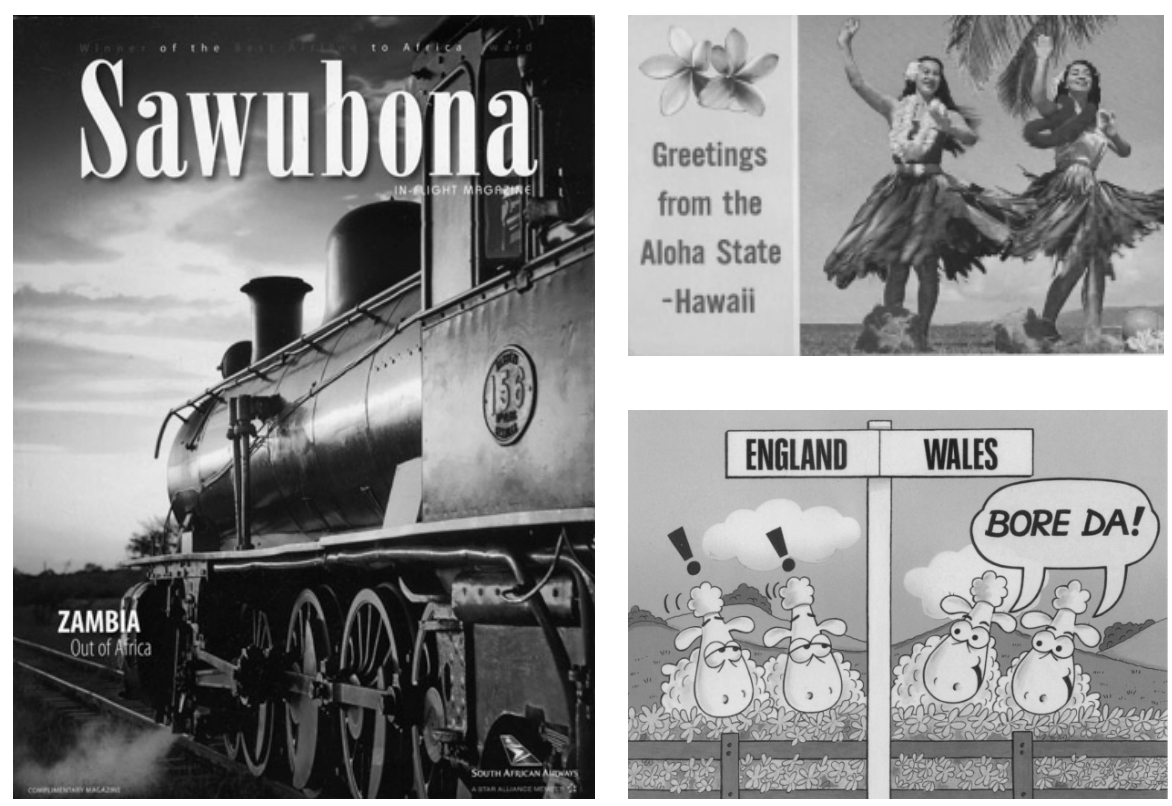

\section{welcome to amazing california!}

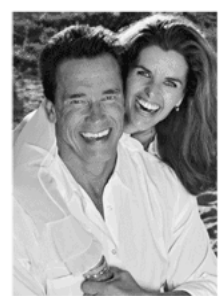

You have chosen to visit one of the most diverse, exciting, and beautiful destinations in the world. Maria and I are proud to serve the 36 million people of California, and we hope you will be a frequent traveler to our Golden State.

To help guide you on your journey, we are pleased to present you with this copy of our beautiful California 2009 Official State Visitor's Guide" ${ }^{\mathrm{ps}}$, a resource for planning every facet of your trip. We think you'll find it not only useful during your stay, but a great way to plan for future California vacations.

So get started! We hope your trip is everything you want it to be, and that when you leave, you'll be saying "I'll be back."

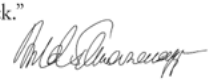

GOVERNOR ARNOLD SCHWARZENEGGER

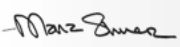

FIRST LADY MARIA SHRIVER

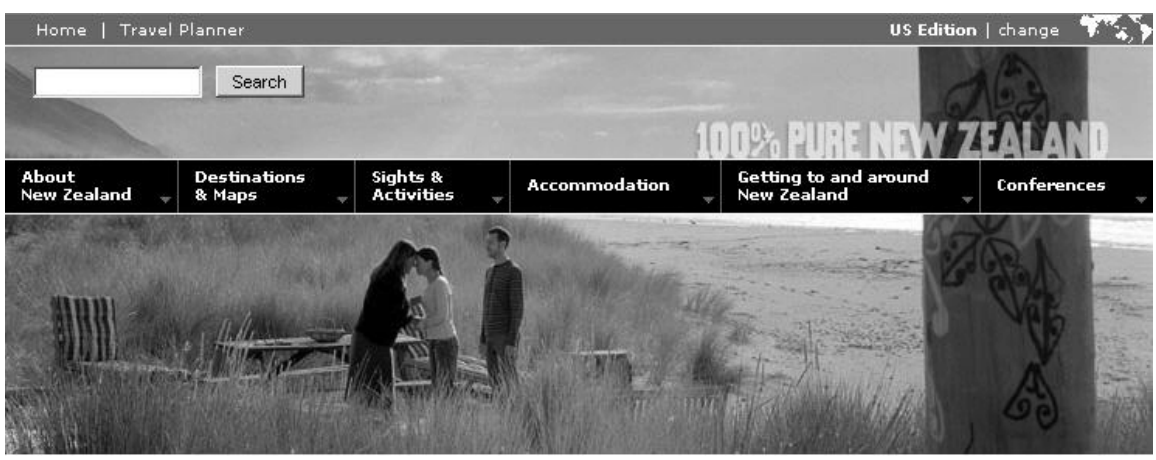

Figures 3-7. The ubiquitous welcome of tourism 
lage Welcome, "gift" presentation, various speeches throughout the night, and so on.

One of such privileges includes the performance of a hongi with the guide/ driver in front of all the other tourists on the bus before its departure for Tamaki Maori Village, as represented in the following extract:

\section{Extract 6: Didn't he do well?}

$G=$ Guide (Driver), $K=$ Kenny, the "chief" tourist, $T=$ Unidentified tourists

1 G: for all you people from different tribes (.) this is how we the

$2 \quad$ Maori people will usually greet each other (.) grab my right

3 hand Kenny (.) (off mike) stand up stand up

$4 \quad$ (Kenny stands; he towers over the driver)

5 T: (light laughter) (1)

6 G: now go down on the step (Kenny goes one step down)

7 T: (laughter) (2)

8 G: ok we- (.) put your left hand on my shoulder Kenny (1) ok

9 (.) now what we do, we press our noses together twice (.)

10 and then we say kia ora ok (.) nice and gentle (.) don't go

11 (thrusts his head forward quickly towards Kenny's face;

12 Kenny tilts his head backwards in a reflex)

13 T: (light laughter) (2)

14 G: and whatever you do: (.) don't kiss me.

[

$15 \mathrm{~K}: \quad$ (inaudible speech to Guide)

16 T: (continued laughter) (2)

17 (Guide and Kenny perform a hongi, cameras flash)

18 G: kia ora: didn't he do well (.) how-bout a big round=

19 T: (applause $4 \mathrm{sec}$.; loud female voice) yeeeahh

20 G: =of applause for Kenny (.) my people interpret the hongi

21 like this when the two noses come together (.) it's the

22 sharing of common breath creating a legion of friendship

23 (1) as a point of interest for you, we the Maori tribe here in

24 Te Arawa are familiar to all this area of Rotorua and Bay of

25 Plenty (.) we are the only Maori tribe in New Zealand that

26 hongi twice (.) all other tribes do it once (.) that's our

27 trade mark. (.) we're now gonna pull out rangatira our big

28 kahuna, the big chief Ken here to the entrance way (.) I'll

29 make the official welcome the challenge you're gonna

30 have a wonderful evening (.) kia ora

31 T: (loud voices) kia ora 
Although the hongi is framed as a typical Maori greeting (lines 1-2) and as a way of establishing "a legion of friendship" (line 22) between two people, the guide's display and "lesson" in Maori etiquette has an undercurrent of cultural subversion and resistance to dominant ideologies of tourism. The guide does not unambiguously adopt a stance of a friendly, deferential and subservient host. Under the guise of humour reminiscent of genres where mock-aggression and mild humiliation are part of the participation ritual (e.g. TV quizshows), he positions Kenny, the archetypal powerful and wealthy Westerner about to be exposed to "Pre-European lifestyle experience of customs and traditions" (http://www.maoriculture.co.nz/ Maori\%20Village/Home), as a relatively powerless and ignorant "foreigner". In order to "teach" Kenny the hongi ritual, the guide instructs him to adopt appropriate body posture. When Kenny comes to the front of the coach and faces the guide, the latter unceremoniously orders Kenny to go one step down, to reduce the difference in their height - having their faces at the same level is more amenable to hongi and symbolically maintains a proxemic equilibrium between the two men. The driver uses unmitigated directives, "stand up stand up" (line 3), "now go down on the step" (line 6), reminiscent of an adult disciplining a child, and this "bossing" Kenny around elicits outbursts of laughter from the onlookers on the coach.

In lines 10-11, the guide teases Kenny, implying that he is likely to hongi inappropriately - "nice and gentle (.) don't go (thrusts his head forward...)". The guide's hyperbolic head-butt is clearly an exaggeration for comic effect as he cannot realistically expect Kenny to act in such a foolish manner. The guide also seems to intentionally frighten Kenny with his mock head-but only to elicit a reaction of slight panic from Kenny and more laughter from the other tourists. Another ridiculing turn at Kenny's expense is the guide's teasing, heteronormative joke, "and whatever you do: don't kiss me" (line 14). The guide then proceeds with the hongi (line 17) and again positions Kenny as a childlike figure who deserves a "round of applause" as a reward for his performance (another game show-like feature). The guide then appears in total control of the situation, a knowledgeable expert, as well as a mocking director-choreographer of the scene, blatantly "Othering" (Jaworski and Coupland 2005) Kenny by adopting the key of teasing and ridicule. Indeed, the guide's control over this intercultural exchange is also manifested in his artful management of tourists' "crossing" into Maori by his constant pronominal ingrouping/outgrouping; visitors are reminded that they ("you people") are outsiders merely playing at being Maori ("we"). 


\section{Tourism discourse and/as banal globalization}

If the system is to work, the agents must not be entirely unaware of the truth of their exchanges, while at the same time they must refuse to know and above all to recognize it. In short, everything takes place as if agents' practice were organized exclusively with a view to concealing from themselves and from others the truth of their practice ... (Bourdieu 1977: 6)

We started this paper with one of Pierre Bourdieu's well-known observations about the nature of symbolic power/privilege; we start our conclusion with his extension of this idea. In both cases, we are reminded of the fundamental power of language in the contexts of everyday life; how the value of symbolic resources like language is inextricably tied to the political/economic privilege (or not) of speakers, and how easily - readily, even - those who benefit most from the inequalities of symbolic markets misunderstand (or "misrecognize", to use Bourdieu's own terms) their privilege. In the context of tourism as a global cultural industry we find the role of local languages exemplifying a number of ways that Bourdieu's critique rings true.

Following Bourdieu (also 1991), all linguistic exchanges are also economic exchanges; however, under the new economic conditions of globalization, existing language forms and configurations (e.g. bilingualism) are put to new uses, gain new value and become objects of intense scrutiny, as well as vehicles and sites of ideological struggle, contestation, legitimation and authentication of ethnic, national and other subject positions. In the context of tourism, this is especially clear in the proliferation of theme parks, open-air museums, festivals and spectacles laying out displays of ethnicity, nationality, culture, urban or industrial heritage through the (re-)invented narratives of group origins, history and present-day lives (e.g. Kirshenbatt-Gimblett 1998; Bruner 2005; Heller 2011). These are also the most obvious areas of tourism-driven activity, where language (and other semiotic codes) become vehicles of explicit staging (Edensor 2001) or "high performance" (N. Coupland 2007) in which gathered (rather than simply co-present) participants overtly orient to the formal properties of code through metapragmatic commentary and the evaluation, translation and labelling of linguistic items. Such performances are heavily marked by claims to ownership, belonging and authenticity, or, conversely, by pragmatic instrumentalism, playfulness and appropriation, and not infrequently by a mixture of all these positions dynamically and dialectically negotiated in the process of staged, ritualized enactments and interactions. The role of language in identity formation is crucial, then, but not as straightforward and clear-cut as might be assumed - there is no one-to-one correspondence between linguistic units and ethnic, social or cultural formations (Le Page and Tabouret-Keller 1985; 
for discussion see N. Coupland 2006). Sociolinguistic items, be they language codes or subtle phonological variants, may be strategically deployed as indexes of specific identities, but their projection and interpretations are always filtered through a plethora of objective and subjective dimensions of self- and otherperception, uptake, interpretive frames and communicative goals, uptake and the political economy of difference (Heller 2003). For example, as observed by Rampton (1995), traditional conceptions of what it is to be a native speaker break down when instrumental language use is separated from its symbolic value as a means of manifesting and asserting one's ethnic or national allegiances or loyalties, or when language inheritance is separated from language allegiance and the degree of linguistic expertise. Likewise, in the context of tourism, we see speakers deploying "old" linguistic resources in novel forms, styling self and other in new, often surprising ways, playing with social norms and establishing new regimes of truth, and unexpectedly conflating instrumental and emotive uses of language, or shifting between use-value and exchange-value.

Even though tourists may experience their encounters with hosts as singular, most tourist-host interactions are ritualized (Jaworski and Thurlow 2011), ranging from low-level "play" with relatively little attention to the accountability to an audience (Bauman 2001 [1975]), through to "mundane" and "high" or "artful" performances (cf. reference to N. Coupland, above). The performative nature of the exchanges in our Extracts 1, 3, 4, and 5, for example, is certainly heightened by their mediated nature which accords the status of ratified audience to the radio listeners and TV viewers. All the same, the insertion of "foreign" languages into tourists' talk, together with laughter, jokey metapragmatic comments, intentional and unintentional "mangling" of the target forms re-keys (Goffman 1974) these greeting sequences, introductions and service encounters into humorous, make-believe greeting sequences, introductions and service encounters. In Extract 5, Ken enacts a ritual hongi greeting with the guide in which he is symbolically stripped of his status as an adult, middle-class, White American and assumes a performed, "as-if" status (Turner 1974) as a Maori novice in an initiation ritual.

All of these strips of activity then are ritualized, performative, self-reflexive (self-positioning) and dynamic (reframing), involving verbal and nonverbal elements from two or more recognizable linguistic codes that cannot be easily juxtaposed as pre-figured, separate and discrete "languages". Associated predominantly with urban, ludic and playful language use, such texts have been variously referred to as heteroglossic (after Bakhtin 1981), transidiomatic (Jacquemet 2005), crossed (Rampton 1995), polylingual (Møller 2008), or metrolingual (Otsuji and Pennycook 2010, following Maher's 2005, 2010 notion of metroethnicity). In Pennycook's characterization of metrolinguistic practice the idea of 
playfulness resurfaces as one "in which people of different and mixed backgrounds use, play with and negotiate identities through language; it does not assume connections between language, culture, ethnicity, nationality and geography, but rather seeks to explore the contingencies of these categories; its focus is not on language systems but on languages as emergent from contexts of interaction" (2010: 85).

No doubt, tourist multilingual practices demonstrated by our data (or models for tourist multilingualism as offered by the guidebook glossaries) draw on their situated, local knowledge of what constitutes (or not) the target language. For this reason, we may think of their multilingual competencies as "symbolic" (Kramsch 2006; Kramsch and Whiteside 2008), i.e. only appropriating or approximating someone else's language, although also, possibly, enriching their own "communicative competence" (Hymes 1972) with additional resources freeing up new "embodied experiences, emotional resonances, and moral imaginings" as part of the exchange of symbolic goods under globalization (Kramsch 2006: 251). However, as Kramsch observes, symbolic competence is not so much a set of identifiable linguistic skills.

Rather, it is a mindset that can create "relationships of possibility" or affordances (van Lier 2004: 105), but only if the individual learns to see him/herself through his/her own embodied history and subjectivity and through the history and subjectivity of others. Our symbolic survival is contingent on framing reality in the way required by the moment, and on being able to enter the game with both full involvement and full detachment. In this sense, the notion of symbolic competence is a late modern way of conceiving of both communicative and intercultural competence in multilingual settings. (Kramsch and Whiteside 2008: 668; our emphasis).

Trying out snippets of local languages by tourists may indeed be greeted by hosts with pleasure as acts of tourists' making an "effort" to engage, show appreciation and involvement with the above), but rituals and performances may be as much a source of enjoyable enhancement of experience as a fearsome act with the potential to subvert the status quo (cf. Bauman 2001 [1975]). All communicative acts laden with a high dose of meta-cultural commentary or staging are rich sites of ideological work, including manifestation of linguistic ideologies, which "are significant for social as well as linguistic analysis because they are not only about language. Rather, such ideologies envision and enact links of language to group and personal identity, to aesthetics, to morality, and to epistemology" (Woolard and Schieffelin 1994: 55-56). No doubt, it is easy to interpret our data "merely" as allowing the tourists to step outside their "everyday" identities and slip into non-committal, innocent and playful role-play of a cultural "Other". 
However, as noted above, the seemingly innocent here-and-now of tourist-host interactions is rooted in broader historical trajectories of travel, colonization, global inequalities and privilege, which reminds us of Blommaert's (2005: 131) argument that "[t]he synchronicity of discourse is an illusion that masks the densely layered historicity of discourse". And as we have noted above with reference to Jane Hill's (2008) work, taking on tourist languages and identities as material for humorous transformations of tourist identities has a more profound, language ideological effect of re-asserting the tourist as having the upper hand in their dealings with hosts. Unless, that is, hosts use precisely the same strips of activity (cf. Extract 6, above) to turn the tables on the tourists and humorously but pointedly reverse the power dynamic through play and deploy their cultural and linguistic heritage as an instrument of power/knowledge.

At a more general level, however, for us, the ideological force realized in - or generated by - the collective actions of tourists orienting to or displaying their symbolic competencies in the languages of their travel destinations lies in what we have been calling banal globalization (Thurlow and Jaworski 2010, 2011) in parallel with Szerszynski and Urry's $(2002,2006)$ term "banal globalism", and following the ideas of Mike Billig (1995, on "banal nationalism") and Ulrich Beck (2006, on "banal cosmopolitanism"). We choose to invoke the notion of banality for framing and understanding tourism discourse as being rooted in everyday communicative actions and textual practices - including those mediatized moments in popular culture (e.g. the broadcast media). By "everyday" we do not mean to say that these actions/practices are either foolish or inconsequential: on the contrary. It is, we suggest, at the level of "innocent" texts and "harmless" (inter)actions that globalization is actually realized. For example, Szerszynski and Urry (2002) find examples of "globalizing" imagery in everyday, recurring TV imagery which includes globes, bird's-eye-views of generic "global" environments, images of the "exotic" Others consuming global brands and products, children standing for the globe in charitable appeals, and so on. These discursive practices may well be trite but they are far from trivial. Just as "small talk" is always pragmatically speaking "big talk" (cf. J. Coupland 2000) and just as reiterative performances of gender solidify and naturalize the "heteronormative matrix" (Butler 1990), so too do the mundane practices embodied and mediated - of tourism turn out to be global in their reach and possibly also in their impact.

\section{Acknowledgements}

We are grateful to Giorgia Aiello for her help with thinking through the pragmalinguistic implications of Rick Steves' use of Italian in Extract 1 and also the confusing (even to a native speaker) Italian in Extract 3. We also thank Panama 
Authority of Tourism and the New Zealand Tourism Board for permission to reproduce their materials. Every reasonable effort was made to contact copyright holders for images which are otherwise reproduced under "fair use" standards.

\section{Notes}

1. The orginal broadcast of the "Rome City Guide" can be downloaded from Rick Steves' own archives at <http://www.ricksteves.com/radio/archive.htm\#134a>.

\section{References}

Agar, Michael. 1994. Language shock: Understanding the culture of conversation. New York: William Morrow and Company.

Bakhtin, Mikhail M. 1981. The dialogic imagination: Four essays [ed. Michael Holquist]. Austin: University of Texas Press.

Barthes, Roland. 1977[1964]. Rhetoric of the image. In Image, Music, Text, 32-51. New York: Hill and Wang.

Bauer, Laurie and Peter Trudgill. (eds.). 1998. Language myths. New York: Penguin Books.

Bauman, Richard. 2001 [1975]. Verbal art as performance. In Alessandro Duranti (ed.), Linguistic anthropology: A reader, 165-188. Malden, MA: Blackwell.

Bauman, Zygmunt. 1998. Globalization: The human consequences. Cambridge: Polity. Beck, Ulrich. 2006. The cosmopolitan vision. Cambridge: Polity.

Bell, Allan. 2009. Language style as audience design. In Nikolas Coupland and Adam Jaworski (eds.), The new sociolinguistics reader, 265-275. Basingstoke: Palgrave Macmillan.

Bhattacharyya, Deborah P. 1997. Mediating India: An analysis of a guidebook. Annals of Tourism Research, 24. 371-389.

Billig, Michael. 1995. Banal nationalism. London: Sage.

Blommaert, Jan. 2005. Discourse: A critical introduction. Cambridge: Cambridge University Press.

Boorstin, Daniel. 1964. The image: A guide to psuedo-events in America. New York: Harper.

Bourdieu, Pierre. 1977. Outline of a theory of practice. Cambridge: Cambridge University Press.

Bourdieu, Pierre. 1991. Language and symbolic power [ed. J. B. Thompson; trans. G. Raymond and M. Adamson]. Cambridge: Polity Press.

Bruner, Edward M. 2005. Culture on tour: Ethnographies of travel. Chicago: University of Chicago Press.

Butler, Judith. 1990. Gender trouble: Feminism and the subversion of identity. New York: Routledge. 
Cameron, Deborah. 2000. Styling the worker: Gender and the commodification of language in the globalized service economy. Journal of Sociolinguistics, 4. 323-347.

Coupland, Justine. (ed.). 2000. Small talk. London: Longman.

Coupland, Nikolas. 2006. The discursive framing of phonological acts of identity: Welshness through English. In Janina Brutt-Griffler and C. Evans Davies (eds), English and ethnicity, 19-48. Basingstoke: Palgrave Macmillan.

Coupland, Nikolas. 2007. Style: Language variation and identity. Cambridge: Cambridge University Press.

Coupland, Nikolas (ed.). 2010. The handbook of globalization. Oxford: Wiley-Blackwell.

Crang, Mike. 1999. Knowing, tourism and practices of vision. In David Crouch (ed.), Leisure/tourism geographies: Practices and geographical knowledge, 238-256. London: Routledge.

Cronin, Michael. 2000. Across the lines: Travel, language, translation. Cork: Cork University Press.

Dunn, David. 2005. "We are not here to make a film about Italy, we are here to make a film about me ..." British television holiday programmes' representations of the tourist destination. In David Crouch, Rhona Jackson and Felix Thompson (eds.), The media and the tourist imagination: Converging cultures, 154-169. London: Routledge.

Dunn, David. 2006. Singular encounters: Mediating the tourist destination in British television holiday programmes. Tourist Studies, 6. 37-58.

Duranti, Alessandro. 1997. Universal and culture-specific properties of greetings. Journal of Linguistic Anthropology,7. 63-97.

Edensor, Tim. 2001. Performing tourism, staging tourism: (Re)producing tourist space and practice. Tourist Studies, 1(1). 59-81.

Favero, P. 2007. "What a wonderful world!": On the "touristic ways of seeing", the knowledge and the politics of the "culture industries of otherness". Tourist Studies, 7(1). 51-81.

Foucault, Michel. 1976. The birth of the clinic. London: Tavistock.

Franklin, Adrian and Mike Crang. 2001. The trouble with tourism and travel theory. Tourist Studies, 1. 5-22.

Goffman, Erving. 1974. Frame analysis: An essay on the organization of experience. New York: Harper \& Row.

Hannerz, Ulf. 1996. Transnational connections: Culture, people, places. London: Routledge.

Heller, Monica. 2003. Globalization, the new economy and the commodification of language and identity. Journal of Sociolinguistics, 7. 473-498.

Heller, Monica. 2011. Paths to post-nationalism. New York: Oxford University Press.

Hill, Jane. 2001 [1998]. Language, race, and white public space. In Alessandro Duranti (ed.), Linguistic anthropology: A reader, 450-464. Malden, MA: Blackwell.

Hill, Jane. 2008. The everyday language of White racism. Oxford: Blackwell.

Hymes, Dell. 1972. On communicative competence. In John Pride and Janet Holmes (eds.), Sociolinguistics, 269-283. Harmondsworth: Penguin. 
Irvine, Judith. 1997. When talk isn't cheap: Language and political economy. In Donald Brenneis and Ronald Macaulay (eds.), The matrix of language: Contemporary linguistic anthropology, 258-283. Boulder, CO: Westview.

Jack, Gavin and Alison Phipps. 2003. On the uses of travel guides in the context of German tourism to Scotland. Tourist Studies, 3. 281-300.

Jacquemet, Marco. 2005. Transidiomatic practices: Language and power in the age of globalization. Language and Communication, 25. 257-277.

Jaworski, Adam. 2009. Greetings in tourist-host encounters. In Nikolas Coupland and Adam Jaworski (eds.). The new sociolinguistics reader, 662-679. Basingstoke: Palgrave Macmillan.

Jaworski, Adam and Justine Coupland. 2005. Othering in gossip: "you go out you have a laugh and you can pull yeah okay but like...". Language in Society, 34. 667-694.

Jaworski, Adam and Crispin Thurlow. 2009. Talking an elitist stance: Ideology and the discursive production of social distinction. In Alexandra Jaffee (ed.), Stance: Sociolinguistic perspectives, 195-226. New York: Oxford University Press.

Jaworski, Adam and Crispin Thurlow. 2010. Language and the globalizing habitus of tourism: A sociolinguistics of fleeting relationships. In Nikolas Coupland (ed.), The Handbook of Language and Globalisation, 256-286. Oxford: Wiley-Blackwell.

Jaworski, Adam and Crispin Thurlow. 2011. Making contact: Language, tourism and globalization. London: Routledge

Kirshenblatt-Gimblett, Barbara. 1998. Destination culture: Tourism, museums, and heritage. Berkeley: University of California Press.

Kramsch, Claire. 2006. From communicative competence to symbolic competence. The Modern Language Journal, 90. 249-252.

Kramsch, Claire and Anne Whiteside. 2008. Language ecology in multilingual settings: Toward a theory of symbolic competence. Applied Linguistics, 29. 645-671.

Le Page, Robert B. and Andrée Tabouret-Keller. 1985. Acts of identity: Creole-based approaches to language and ethnicity. Cambridge: Cambridge University Press.

Lash, Scott and John Urry. 1994. Economies of signs and spaces. London: Sage.

Lippi-Green, Rosina. 1997. English with an accent: Language, ideology, and discrimination in the United States. New York: Routledge.

Maher, John C. 2005. Metroethnicity, language, and the principle of Cool. International Journal of the Sociology of Language, 11. 83-102.

Maher, John C. 2010. Metroethnicities and metrolanguages. In N. Coupland (ed.), The handbook of language and globalization. Malden, MA: Wiley-Blackwell. pp. 575591.

Møller, Janus S. (2008). Polylingual performance among Turkish-Danes in late-modern Copenhagen. International Journal of Multilingualism, 5. 217-236.

Otsuji, Emi and Alastair Pennycook. 2010. Metrolingualism: Fixity, fluidity and language in flux. International Journal of Multilingualism, 7. 240-254.

Pennycook, Alastair. 1989. The concept of method, interested knowledge, and the politics of language learning. TESOL Quarterly, 23. 589-618.

Pennycook, Alastair. 2010. Language as a local practice. London: Routledge. 
Phipps, Alison. 2007. Learning the arts of linguistic survival: Languaging, tourism, life. Clevedon: Channel View.

Rampton, Ben. 1995. Crossing: Language and ethnicity among adolescents. London: Longman.

Szerszynski, Bronislaw and John Urry. 2006. Visuality, mobility and the cosmopolitan: Inhabiting the world from afar. The British Journal of Sociology, 57. 113-131.

Thurlow, Crispin 2004. Relating to our work, accounting for our selves: The autobiographical imperative in teaching about difference. Language and Intercultural Communication, 4. 209-228.

Thurlow, Crispin and Adam Jaworski. 2010. Silence is golden: Elitism, linguascaping and "anti-communication" in luxury tourism. In Adam Jaworski and Crispin Thurlow (eds.), Semiotic Landscapes: Language, Image, Space, 187-218. London: Continuum.

Thurlow, Crispin and Adam Jaworski. 2010. Tourism discourse: Language and global mobility. London: Palgrave MacMillan.

Thurlow, Crispin and Adam Jaworski. 2011. Banal globalization? Embodied actions and mediated practices in tourists' online photo-sharing. In Crispin Thurlow and Kristine Mroczek (eds.), Digital discourse: Language in the new media. New York: Oxford University Press.

Turner, Victor. 1974. Dramas, fields, and metaphors: Symbolic action in human society. Ithaca: Cornell University Press.

Urry, John. 2002. The Tourist Gaze [2nd ed.]. London: Sage.

Urry, John. 2007. Mobilities. Cambridge: Polity.

Van Lier, Leo. 2004. The ecology and semiotics of language learning. A sociocultural perspective. Dordrecht: Kluwer Academic.

Woolard, Kathryn A. and Bambi B. Schieffelin. 1994. Language ideology. Annual Review of Anthropology, 23. 55-82.

Crispin Thurlow, thurlow@uw.edu, is Associate Professor of Interdisciplinary Arts \& Sciences at the University of Washington (USA) where he also holds adjunct positions in Linguistics, Anthropology and Communication. His recent books include Tourism Discourse: Language and Global Mobility (with Adam Jaworski, 2010, Palgrave Macmillan) and Digital Discourse: Language in the New Media (with Kristine Mroczek, 2011, Oxford University Press).

Adam Jaworski, Jaworski@cardiff.ac.uk, is Professor of Language and Communication at Cardiff University (Wales, UK). His books include Semiotic Landscapes: Language, Image, Space (with Crispin Thurlow, 2010, Continuum) and Discourse, Communication and Tourism (with Annette Pritchard, 2005, Channel View). Adam is also co-editor of the book series Oxford Studies in Sociolinguistics. 
Copyright of Bloomsbury Review of Applied Linguistics \& Communication is the property of De Gruyter and its content may not be copied or emailed to multiple sites or posted to a listserv without the copyright holder's express written permission. However, users may print, download, or email articles for individual use. 
Copyright of Applied Linguistics Review is the property of De Gruyter and its content may not be copied or emailed to multiple sites or posted to a listserv without the copyright holder's express written permission. However, users may print, download, or email articles for individual use. 